\title{
Persepsi, Motivasi, dan Kinerja Mahasiswa Akuntansi Syariah atas Pembelajaran Berbasis Kasus
}

\author{
Vega Wafaretta ${ }^{1}$, Muhammad $^{2 *}$, Dian Syariati ${ }^{3}$ \\ 1,2,3 Universitas Negeri Malang, Kota Malang- Indonesia
}

\section{A R T I C L E I N F O}

Article history:

Received October, 252021

Received in revised form

November, 302021

Accepted December, 23

2021

Available online December, 252021

\section{Kata Kunci:}

Akuntansi syari'ah, kasus,

pembelajaran.

Keywords:

Case, learning, sharia

accounting.

\begin{abstract}
A B S T R A K
Berkembangnya industri keuangan syari'ah menyebabkan perguruan tinggi harus mempersiapkan peserta didiknya. Pembelajaran berbasis kasus menjadi salah satu upaya untuk merespon kebutuhan industri akan sumber daya manusia yang memiliki skill lebih untuk bekerja. Oleh karena itu, penelitian ini bertujuan untuk mengukur efektivitas pembelajaran berbasis kasus yang diukur dengan variabel persepsi, motivasi, dan kinerja. Berdasarkan hasil uji eksperimen yang dilakukan pada 91 peserta didik yang dibagi menjadi dua kelas, tidak ditemukan adanya perbedaan persepsi, motivasi, dan kinerja belajar antara kelas berbasis kasus dan kelas instruksional. Hal ini dapat disebabkan karena pembelajaran berbasis kasus dapat lebih efektif pada kelas dengan jumlah peserta didik yang lebih kecil dan dalam jangka waktu yang lebih panjang. Selain itu, faktor pengalaman peserta didik dalam menerima dan menganalisis kasus sebelumnya juga menjadi kendala dalam efektivitas pembelajaran berbasis kasus. Studi ini juga menemukan motivasi menjadi variabel yang sangat penting dalam meningkatkan persepsi atas perolehan skill dan kinerja belajar pada pembelajaran berbasis kasus.
\end{abstract}

\section{A B S T R A C T}

The development of the sharia financial industry causes universities to prepare their students. The casebased learning is one way to response to the industry's need for human resources with more skills to be ready for work. Therefore, this study aims to measure the effectiveness of case-based learning as measured by the variables of perception, motivation, and performance. Based on the results of experimental tests conducted on 91 students who were divided into two classes, there were no differences in perceptions, motivations, and learning performance between case-based classes and instructional classes. This could be because case-based learning can be more effective in classes with a smaller number of students and for a longer period of time. In addition, the experience of students in receiving and analyzing previous cases is also an obstacle in the effectiveness of case-based learning. This study also found motivation to be a very important variable in increasing perceptions of skill acquisition and learning performance in case-based learning. 


\section{Pendahuluan}

Pengembangan kurikulum dan pembelajaran merupakan suatu keharusan bagi sebuah institusi pendidikan, hal ini mengingat kebutuhan akan perkembangan jaman serta teknologi tidak dapat dihindarkan. Kompetensi alumni perguruan tinggi akan dilihat oleh industri sebagai kualitas dari pembelajaran yang diselenggarakan oleh institusi perguruan tinggi tersebut (Coskun et al., 2019; Hussin, 2018). Pada bidang akuntansi syari'ah, berkembangnya bisnis dan kompleksitas transaksi syari'ah yang ada, juga membuat pedoman pencatatan transaksi entitas syari'ah di Indonesia semakin berkembang. Secara global, aset keuangan syariah telah mencapai US\$2,88 triliun pada tahun 2019 dan diperkirakan akan terus tumbuh hingga US\$3,60 triliun pada tahun 2024 (Otoritas Jasa Keuangan - OJK, 2020). Untuk itu, perguruan tinggi juga dipaksa untuk mengubah pembelajaran dan kurikulum serta materi perkuliahaan yang sesuai dengan kebutuhan industri.

Pada praktiknya, entitas syari'ah di Indonesia diwajibkan untuk mematuhi prinsip akuntansi yang berlaku umum bagi entitas syari'ah yaitu Pernyataan Standar Akuntansi (PSAK) Syari'ah. Dari sisi regulasi, standar akuntansi entitas syariah juga terus mengalami pembaruan, seperti pada tahun 2021 terdapat perubahan atas akuntansi transaksi ijarah, akuntansi wakalah, serta akuntansi penurunan nilai atas transaksi murabahah. Hal ini dilakukan untuk menyesuaikan dengan kebutuhan industri entitas syari'ah yang ada. Untuk itu, dalam rangka menyiapkan lulusan yang mempunyai kompetensi dan pemahaman terhadap PSAK entitas syari'iah di Indonesia, merupakan keharusan bagi entitas pendidikan untuk memperbaiki pembelajaran.

Pembelajaran akuntansi syari'ah selama ini berfokus pada pemahaman transaksi syari'ah secara teori, hal ini dirasa kurang mengingat model transaksi syari'ah yang dihadapi oleh calon akuntan pada praktiknya memiliki kompleksitas yang tinggi. Hal ini dikarenakan seringkali ada batasan syariah dalam bertransaksi dan perlakuan akuntansi atas praktik syariah tersebut. Salah satu contohnya adalah wakaf permanen dan temporer di praktik yang masih menemui tantangan dalam pencatatan atas aset tersebut.

Untuk itu mahasiswa perlu untuk lebih mengenal dan mampu menganalisis kasus terkini dan menghubungkannya dengan teori (Kardash \& Wallace, 2001). Sistem perkuliahan dengan mengkaji kasus, atau disebut cased based learning (CBL) dalam akuntansi syari'ah ditujukan untuk memahami proses pengukuran, pengakuan, penyajian transaksi yang diharapkan memberikan pemahaman kepada mahasiswa tentang gambaran praktik yang relevan (Kim et al., 2012; Bergmann et al., 2003). Cased based learning juga diyakini dapat mempersempit kesenjangan antara teori yang telah dipelajari di kelas dengan kehidupan nyata (Ashbaugh \& Kasten, 1991).

Oleh karena itu, studi ini mengembangkan sebuah modul akuntansi syari'ah yang berbasis kasus dengan mengangkat isu-isu terkini. Melalui pembelajaran berbasis kasus, mahasiswa dapat mengenali praktik di lapangan yang ternyata memerlukan akuntansi yang berbeda dengan catatan pertimbangan khusus. Selanjutnya modul tersebut akan diberikan kepada kelompok mahasiswa yang diberikan instruksi tentang cara belajar dan penggunaan modul. Setelah itu, kelompok mahasiswa tersebut dilakukan penilaian terkait dengan kinerja dan persepsi mahasiswa atas skill yang diperoleh dari pembelajaran berbasis kasus. Hasil penilaian kinerja yang ada, akan dibandingkan dengan kelompok mahasiswa yang hanya memperoleh pembelajaran instruksional.

Dengan demikian, studi ini bertujuan untuk 1) menguji perbedaan persepsi mahasiswa atas skill yang diperoleh dari pembelajaran berbasis kasus, motivasi belajar dengan pembelajaran berbasis kasus, serta kinerja belajar mahasiswa antara mahasiswa yang diberikan modul pembelajaran studi kasus dengan kelompok mahasiswa yang mendapatkan pembelajaran instruksional; serta 2) menguji apakah persepsi atas perolehan skill dan kinerja mahasiswa akan berbeda tergantung motivasi belajar mahasiswa. Motivasi belajar ini mempunyai potensi untuk memberikan efektivitas yang berbeda atas perolehan skill dan kinerja (Dahl \& Smimou, 2011; Hytti et al., 2010).

\section{Kajian Pustaka}

\section{Pembelajaran Berbasis Kasus}

Istilah pembelajaran berbasis kasus bukan merupakan hal baru pada dunia pendidikan. Istilah pembelajaran berbasis kasus telah menjadi salah satu bagian dari manajemen aktivitas pembelajaran (Wines, et al). Terdapat beberapa literatur yang telah mendefinisikan pembelajaran berbasis kasus, diantaranya Rourke dan Anderson (2002) menyatakan pembelajaran berbasis kasus merupakan suatu strategi pembelajaran, yang menuntut mahasiswa untuk lebih aktif dalam menggunakan pengetahuan dan kemampuan analisis yang mereka miliki, kemampuan analisis tersebut digunakan untuk menjawab permasalahan yang telah diskenariokan berdasarkan kasus nyata. Sedangkan menurut Aamont dan Plaza 
(1996) menyatakan pembelajaran bertujuan untuk memecahkan kasus dan memberi solusi atas permasalahan yang ada berdasarkan pengalaman sebelumnya. Dalam pembelajaran berbasis kasus ini para siswa akan dihadapkan pada situasi yang kompleks, di mana situasi tersebut dapat bersifat nyata dan mendekati kondisi nyata (Giacolani, 2016).

Pengembangan pembelajaran berbasis kasus dimulai dengan menentukan konsep materi yang akan diajarkan, selanjutnya akan dirumuskan capaian pembelajaran mata kuliah yang harus dicapai oleh siswa. Pada penerapannya, siswa akan diberikan sebuah permasalahan atau kasus dan diminta untuk memberikan solusi atas permasalahan yang diberikan. Setelah itu, perwakilan dari kelompok siswa akan mempresentasikan hasil analisis atas kasus yang diberikan dan siswa lain diminta untuk memberikan tanggapan atas hasil presentasi tersebut. Kemudian dosen akan memberikan pertanyaan tentang alas an mengapa siswa memberikan jawaban dan solusi tertentu terhadap kasus tersebut (Giacalone, 2016; Topperzer et al., 2021).

Berdasarkan uraian tersebut, pembelajaran berbasis kasus memang membutuhkan banyak interaksi dan diskusi untuk mengatasi masalah dan membangun solusi yang tepat (Lyons \& Bandura, 2019; Sawyer et al., 2000). Selain untuk menjawab permasalahan yang ada (J.L. Kolodner \& Leake, 1996), metode ini juga menuntut seluruh personil kelas untuk berkontribusi dan berinteraksi secara aktif, sedangkan peran dosen pada pembelajaran ini lebih kepada fasilitator diskusi daripada pemberi materi. Maka dari itu, selain belajar untuk memecahkan kasus yang ada, pada pembelajaran berbasis kasus ini dapat meningkatkan kemampuan interpersonal, komunikasi, dan Kerjasama tim (Barnes et al., 1994 ; Cinneide, 1997); Raza et al., 2020).

\section{Pengembangan Hipotesis}

Pembelajaran berbasis kasus saat ini merupakan salah satu metode untuk memberikan kesempatan kepada siswa untuk menerapkan pengetahuan dan memperoleh keterampilan bernilai tinggi seperti melatih berpikir kritis, pemecahan kasus, pengambilan keputusan, pembelajaran mendalam dan pemahaman realistis. Selain itu, pembelajaran ini ,menuntut siswa untuk berpartisipasi aktif dalam memberikan solusi atas masalah yang bersifat kompleks (Mostafa et al., 2019; Li et al., 2019; Prince, 2004; Lyons \& Bandura, 2020).

Pembelajaran berbasis kasus dianggap lebih baik dalam membentuk pola pikir tingkat tinggi melalui pemahaman dan eksplorasi yang lebih mendalam, dengan menganalisis, mensintesis, mengevaluasi, dan mempertanyakan mengapa dan bagaimana dalam beberapa hal (Nkhoma et al., 2017; Kolodner, 1997; Barnes et al., 1994; McCabe et al., 2009). Oleh karena itu, mahasiswa yang mendapatkan pembelajaran berbasis kasus memiliki persepsi terhadap kompetensi diri lebih baik (Golaghaie et al., 2019). Untuk itu, hipotesis yang dibangun adalah:

H1 : Terdapat perbedaan persepsi mahasiswa atas skill yang diperoleh antara kelas yang mendapatkan pembelajaran berbasis kasus dan kelas menggunakan system pembelajaran instruksional.

Pembelajaran berbasis kasus dapat meningkatkan pengetahuan mahasiswa dengan memberikan pemahaman yang lebih baik atas skenario kasus yang diberikan dan meningkatkan keterikatan dengan materi pembelajaran yang diberikan (Kim et al., 2012; Grassberger \& Wilder, 2015). Pemahaman dan keterikatan dari pembelajaran berbasis kasus ini selanjutnya mendorong kepuasan belajar dan motivasi belajar (Kim et al., 2012; Raza et al., 2020; Heinrich et al., 2012). Hal ini dikarenakan pembelajaran tersebut memberikan pengalaman yang dapat meningkatkan motivasi lebih untuk mempelajari materi daripada pembelajaran instruksional (Mesthrige et al., 2020).

H2 : Terdapat perbedaan motivasi belajar antara kelas kasus dan kelas instruksional.

Sebagaimana dinyatakan oleh (Lyons \& Bandura, 2020b), pembelajaran berbasis kasus mendukung self-regulated learning yang mana mahasiswa dapat mengidentifikasi tujuan dalam belajar serta keinginan untuk meningkatkan kinerja belajar (Plaks et al., 2005; Mesthrige et al., 2020). Pembelajaran berbasis kasus dinilai efektif dalam meningkatkan engagement siswa terhadap materi yang diberikan, hal ini dikarenakan dapat meningkatkan pemahaman dan keterampilan siswa (Raza et al., 2020), serta meningkatkan kepuasan siswa dalam proses pembelajaran (Kim et al., 2012).

H3 : Terdapat perbedaan kinerja belajar antara kelas kasus dan kelas instruksional.

Efektivitas pembelajaran berbasis kasus dalam membangun persepsi skill yang diperoleh dapat tergantung dari motivasi peserta didik untuk memecahkan permasalahan yang diberikan. Oleh karena itu, tenaga pengajar berupaya mendesain aktivitas kelas yang dapat memotivasi peserta didik. Pengalaman yang diperoleh oleh peserta didik dari modifikasi pembelajaran di kelas, akan mengarahkan orientasi tujuan peserta didik. Karena peserta didik mulai memiliki orientasi tujuan yang ingin dicapai dari pembelajaran, maka target ini akan membentuk motivasi untuk belajar (Deci, 1971; Reeve et al., 2004). Motivasi belajar yang tinggi ini pada akhirnya berdampak pada penilaian mahasiswa atas pengalaman belajar yang terasa menyenangkan (Dahl \& Smimou, 2011) dan evaluasi diri atas perolehan kompetensi 
yang lebih tinggi (Noels et al., 1999). Dengan demikian, evaluasi atas skill yang diperoleh diprediksi berbeda antara mahasiswa yang memiliki motivasi tinggi dan kurang. Hipotesis yang dibangun adalah:

H4 : Terdapat perbedaan persepsi mahasiswa atas skill yang diperoleh dari kasus antara mahasiswa yang memiliki motivasi tinggi dan rendah

Selain mendorong pembentukan persepsi atas perolehan skill, motivasi juga mendorong belajar yang efektif di mana peserta didik dapat menangkap dan membangunan pengetahuan yang utuh (Fordham, 1980). Motivasi ini mengarah pada keterikatan kognitif, ketertarikan untuk belajar, dan target pencapaian yang lebih tinggi. Hal ini pada akhirnya mendorong capaian pembelajaran yang positif (Noels et al., 1999), meningkatkan level kinerja hasil belajar (Hytti et al., 2010), dan kepuasan peserta didik atas pembelajaran (Dahl \& Smimou, 2011). Dengan demikian, kinerja belajar diprediksi berbeda antara mahasiswa yang memiliki motivasi tinggi dan kurang. Hipotesis yang dibangun adalah:

H5 : Terdapat perbedaan kinerja belajar antara mahasiswa yang memiliki motivasi tinggi dan rendah.

\section{Metode}

Penelitian ini merupakan penelitian eksperimen pembelajaran berbasis kasus di mata kuliah akuntansi syari'ah. Populasi penelitian ini adalah seluruh mahasiswa semester 2 Jurusan Akuntansi Fakultas Ekonomi Universitas Negeri Malang, yang menempuh mata kuliah akuntansi syariah. Studi ini dilakukan pada 91 mahasiswa yang dibagi menjadi dua kelompok, yaitu kelompok pertama adalah 65 mahasiswa yang akan dilakukan eksperimen menggunakan pembelajaran berbasis kasus. Sementara itu, kelompok kedua diberikan pembelajaran berbasis instruksional dengan total 36 mahasiswa.

\section{Kelas Eksperimen (Kasus)}

Pada prosesnya, kelas kasus diberikan modul berbasis kasus. Modul terdiri dari materi, tugas kasus kelompok, dan tugas formatif individu. Soal kasus didesain dengan mengangkat isu terkini yang sedang berkembang di praktik. Eksperimen dilakukan pada empat (4) topik, yaitu akuntansi Zakat, Infak, Sedekah (ZIS), sukuk, wa'd, dan wakaf. Kasus yang diangkat adalah kasus mengenai Lembaga Amil Zakat, Infak, dan Sedekah (LAZIS) yang seringkali belum menerapkan akuntansi yang sesuai dengan Standar Akuntansi Keuangan (SAK) seperti hanya mencatat kas masuk dan keluar, belum mencatat aset nonkas, atau perlakuan atas penyaluran ZIS yang melalui perantara. Kasus lainnya terkait macam-macam sukuk dan isu pembeda sukuk dengan obligasi; perlakuan akuntansi atas janji repo (beli Kembali) sukuk; serta pencatatan atas wakaf kas atau nonkas dan permanen atau temporer. Beberapa kasus praktis inilah yang didiskusikan oleh mahasiswa kelas eksperimen. Sementara itu, kelas instruksional tanpa melibatkan kasus praktis terkini.

Dalam kelas yang diberikan pembelajaran berbasis kasus, dosen memberikan pengantar mengenai garis besar materi, yang dilanjutkan dengan pembahasan soal kasus bersama-sama, dan diakhiri dengan penarikan simpulan yang dipandu oleh dosen. Adapun tahapan dalam kelas berbasis kasus sebagai berikut: (Parrado-Martínez \& Sánchez-Andújar, 2020; Lyons \& Bandura, 2020a):

1. Pengantar tentang metode pembelajaran berbasis kasus secara detail ke mahasiswa.

2. Membentuk kelompok 5-6 orang secara acak agar tidak homogen mahasiswa dengan kompetensi yang lebih, berkumpul di satu kelompok.

3. Pada pekan 1 para siswa diberikan materi tentang konsep dasar dan teori yang ada, kemudian mereka akan diberikan modul, setelah itu, dosen akan memberikan instruksi tentang pengerjaan soal kasus yang akan didiskusikan pada pertemuan berikutnya.

4. Pada pekan berikutnya, diskusi pembahasan kasus yang ada di modul yang telah disediakan dimulai, diskusi ini dilakukan dengan metode sinkron atau tatap maya melalui video conference menggunakan aplikasi zoom meeting selama 60 menit. Dalam hal ini, dosen hanya menjadi fasilitator dan mediator dalam diskusi, kemudian mengkonfirmasi hasil jawaban diskusi.

5. Pada pekan ke empat pembelajaran berbasis kasus dilakukan, peneliti melakukan penilaian untuk mengetahui persepsi, motivasi, dan hasil kinerja mahasiswa mengenai pembelajaran berbasis kasus yang telah dilakukan.

\section{Kelas Kontrol (Instruksional)}

Sementara itu, kelas kontrol menggunakan metode konvensional yang mana pembelajaran didominasi oleh dosen dan mekanistik. Mahasiswa diberi materi, kemudian dosen menjelaskan materi, dan membahas contoh penerapan materi. Selanjutnya setiap mahasiswa akan mengumpulkan pengerjaan tugas yang diberikan dan tugas akan dipresentasikan oleh mahasiswa (Sugeng \& Suryani, 2019). Soal diambil dari 
buku yang bersifat tekstual dan belum mencerminkan masalah terkini yang dihadapi pada praktik di lapangan.

\section{Pengukuran}

Variabel persepsi terdiri dari tiga belas (13) pernyataan mengacu pada Mostafa et al. (2019) dan Raza et al. (2020). Persepsi pembelajaran mengukur penilaian diri oleh mahasiswa terkait persepsi mereka atas pembelajaran berbasis kasus setelah mengikuti pembelajaran berbasis kasus selama 4 pekan. Penilaian diri ini dilakukan untuk mengukur apakah mahasiswa telah mencapai tujuan pembelajaran dan memperoleh kompetensi yang diinginkan dari pembelajaran berbasis kasus yang dilakukan. Motivasi belajar mencerminkan kondisi di mana mahasiswa memiliki dorongan belajar untuk mencapai tujuan yang ditargetkan setelah menyelesaikan kegiatan belajar (Nenninger, 2014; Hytti et al., 2010). Motivasi terdiri dari empat (4) pernyataan mengacu pada Raza et al. (2020). Sementara itu, kinerja menunjukkaan capaian peserta didik dalam menyelesaikan tugas tertentu (Kim et al., 2012). Kinerja terdiri dari empat (4) pernyataan mengacu pada Kim et al. (2012). Instrumen menggunakan skala likert 1-5 dari sangat tidak setuju hingga sangat setuju. Kuesioner diisi oleh mahasiswa secara daring melalui googleform.

\section{Metode Analisis Data}

Dalam studi ini, data dianalisis dengan menggunakan uji beda untuk mengetahui perbedaan persepsi, motivasi, dan kinerja mahasiswa kelas kasus dan instruksional. Selain itu, uji beda dilakukan untuk mengetahui bagaimana tingkat motivasi berdampak pada persepsi skill dan kinerja. Oleh karena itu, mahasiswa kelas kasus dikelompokkan menjadi 2, yaitu mahasiswa dengan motivasi tinggi dan rendah untuk mengetahui sejauh mana motivasi penting dalam membentuk persepsi positif atas pembelajaran berbasis kasus. Olah data dilakukan dengan menggunakan SPSS edisi 22.

\section{Hasil dan Pembahasan}

\section{Hasil}

Kelas kasus terdiri dari 2 kelas dengan jumlah 65 mahasiswa dan kelas intruksional terdiri dari 36 mahasiswa. Persepsi, motivasi, dan kinerja mahasiswa kelas kasus dan instruksional disajikan pada Tabel 1 berikut:

Tabel 1. Persepsi, Motivasi Belajar, dan Kinerja Mahasiswa Kelas Kasus dan Instruksional

\begin{tabular}{|c|c|c|c|}
\hline & Ref & $\begin{array}{l}\text { Experiment } \\
\text { (Case) }\end{array}$ & $\begin{array}{c}\text { Control } \\
\text { (Instructional) }\end{array}$ \\
\hline $\begin{array}{l}\text { Persepsi Saudara/i terkait bahan } \\
\text { ajar dan kegiatan pembelajaran } \\
\text { berbasis kasus pada mata kuliah } \\
\text { akuntansi syariah... }\end{array}$ & $\begin{array}{l}\text { Mostafa et al. } \\
\text { (2019); Raza et al. } \\
(2020)\end{array}$ & 4,13 & 4,26 \\
\hline $\begin{array}{l}\text { memberikan pengetahuan yang } \\
\text { relevan terkait akuntansi syariah }\end{array}$ & & 4,35 & 4,50 \\
\hline $\begin{array}{l}\text { meningkatkan pengetahuan tentang } \\
\text { akuntansi syariah }\end{array}$ & & 4,42 & 4,56 \\
\hline $\begin{array}{l}\text { mendukung keterpahaman materi } \\
\text { akuntansi syariah }\end{array}$ & & 4,34 & 4,50 \\
\hline menarik dan memotivasi & & 3,92 & 4,17 \\
\hline $\begin{array}{l}\text { meningkatkan keahlian pemecahan } \\
\text { masalah praktis }\end{array}$ & & 4,09 & 4,00 \\
\hline praktis sesuai dengan di lapangan & & 3,95 & 4,06 \\
\hline $\begin{array}{l}\text { meningkatkan kepercayaan diri } \\
\text { dalam berpendapat }\end{array}$ & & 3,97 & 4,11 \\
\hline tidak monoton & & 3,95 & 4,22 \\
\hline $\begin{array}{l}\text { mendorong berpikir lebih dalam dan } \\
\text { detail (depth thinking) }\end{array}$ & & 4,28 & 4,31 \\
\hline $\begin{array}{l}\text { memberikan ruang lebih untuk } \\
\text { bertanya dan menjawab }\end{array}$ & & 4,14 & 4,44 \\
\hline lebih efektif dalam memahami & & 4,08 & 4,19 \\
\hline
\end{tabular}




\begin{tabular}{|c|c|c|c|}
\hline $\begin{array}{l}\text { lebih mudah dalam merangkum } \\
\text { benang merah materi } \\
\text { mendukung berpartisipasi aktif } \\
\text { dalam diskusi }\end{array}$ & & 4,08 & $\begin{array}{l}4,11 \\
4,28\end{array}$ \\
\hline Motivasi Belajar & Raza et al. (2020) & 3,78 & 3,72 \\
\hline $\begin{array}{l}\text { Saya menghabiskan banyak waktu } \\
\text { untuk belajar mata kuliah Akuntansi } \\
\text { Syariah }\end{array}$ & & 3,66 & 3,50 \\
\hline $\begin{array}{l}\text { Investasi waktu dan tenaga untuk } \\
\text { mata kuliah ini menjadi prioritas saa }\end{array}$ & & 3,51 & 3,39 \\
\hline $\begin{array}{l}\text { Saya memberikan upaya terbaik } \\
\text { untuk mempelajari konten } \\
\text { Akuntansi Syariah }\end{array}$ & & 4,12 & 4,14 \\
\hline $\begin{array}{l}\text { Secara umum, motivasi belajar saya } \\
\text { terhadap mata kuliah Akuntansi } \\
\text { Syariah tinggi }\end{array}$ & & 3,82 & 3,83 \\
\hline Kinerja & Kim et al. (2012) & 3,90 & 4,08 \\
\hline $\begin{array}{l}\text { Saya dapat belajar efektif dari } \\
\text { konten materi }\end{array}$ & & 4,03 & 4,03 \\
\hline $\begin{array}{l}\text { Saya merasakan kemudahan belajar } \\
\text { dari konten materi }\end{array}$ & & 3,85 & 4,06 \\
\hline $\begin{array}{l}\text { Saya dapat belajar dengan cepat dari } \\
\text { konten materi }\end{array}$ & & 3,75 & 3,89 \\
\hline Saya puas dengan konten materi & & 3,95 & 4,36 \\
\hline
\end{tabular}

Berdasarkan Tabel 1, tampak bahwa persepsi mengenai skill yang diperoleh mahasiswa, dan kinerja mahasiswa kelas instruksional lebih tinggi daripada kelas berbasis kasus. Selain itu, tidak ada perbedaan persepsi, motivasi, dan kinerja antara mahasiswa kelas kasus dan instruksional. Hasil ini menolak hipotesis 1, 2, dan 3 bahwa tidak ada perbedaan di antara kedua kelas.

Hasil ini perlu diinvestigasi lebih lanjut mengapa mahasiswa kelas yang diberikan pembelajaran berbasis kasus mempersepsikan skill yang diperoleh sedikit lebih rendah yaitu 4,13 daripada mahasiswa kelas instruksional yaitu 4,26, penelitian ini bertentangan dengan studi yang dilakukan Golaghaie et al (2019) yang menyatakan siswa yang menempuh sistem belajar berbasis kasus memiliki persepsi skill yang lebih tinggi. Dalam studi ini juga ditemukan bahwa kinerja mahasiswa kelas berbasis kasus juga lebih rendah yaitu 3,90 daripada kelas instruksional sebesar 4,08. Namun, motivasi belajar mahasiswa di kelas berbasis kasus lebih tinggi yaitu 3,78 daripada kelas instruksional sebesar 3,72. Oleh karena itu, berdasarkan Tabel 1, perlu dilakukan eksplorasi manfaat dan kendala dari pembelajaran berbasis kasus yang disajikan pada Tabel 2 .

Berdasarkan Tabel 2, manfaat yang diperoleh mahasiswa dalam pembelajaran berbasis kasus sebagaimana dalam literatur terdahulu dapat tercapai, manfaat tersebut diantaranya mahasiswa dapat mengenali praktik kasus riil dan permasalahan di lapangan (Lee et al., 2009). Praktik ini menuntut mahasiswa menganalis dan mengkaitkan antara teori dan praktik (Kardash \& Wallace, 2001; Kim et al., 2012) dan meningkatkan penguasaan materi (Raza et al., 2020). Selain dari segi penguasaan materi, pembelajaran berbasis kasus sebenarnya mendorong perolehan skill seperti belajar mengidentifikasi masalah, meningkatkan keaktifan dalam diskusi, berlatih pengambilan keputusan, dan belajar mandiri (Nkhoma et al., 2014; Mostafa et al., 2019; Heitzmann, 2008; Yoo et al., 2010).

Namun, pada praktiknya, mahasiswa menghadapi beberapa kendala seperti harus memahami teori dan kasus yang masih asing dalam waktu bersamaan, memerlukan lebih banyak waktu, dan lebih sulit dalam mengidentifikasi masalah dan solusi. Dalam hal ini, mahasiswa belum memiliki pengalaman membaca atau mengetahui kasus yang sejenis (Ketler, 1993), sehingga memerlukan upaya lebih seperti ketelitian dan kerjasama tim dalam menyelesaikan kasus. Lebih lanjut, Tabel 3 menyajikan pentingnya tingkat motivasi dalam membentuk persepsi atas pembelajaran berbasis kasus dan kinerja belajar mahasiswa. 
Tabel 2. Manfaat dan Kendala Pembelajaran Berbasis Kasus (CBL)

\begin{tabular}{|c|c|}
\hline \multicolumn{2}{|r|}{ Manfaat Sistem Belajar Berbasis Kasus } \\
\hline $\begin{array}{l}\text { Penguasaan } \\
\text { Materi dan } \\
\text { Kasus }\end{array}$ & $\begin{array}{ll}\text { - } & \text { Memahami sirkulasi di bank syariah } \\
\text { - } & \text { Mengetahui praktik perhitungan zakat } \\
\text { - } & \text { Mengetahui kasus praktis/implementasi akuntansi syariah } \\
\text { - } & \text { Mengetahui permasalahan akad dan akuntansinya di lapangan } \\
\text { - } & \text { Menganalisis kasus sesuai dengan teori } \\
\text { - } & \text { Lebih menguasai materi }\end{array}$ \\
\hline $\begin{array}{l}\text { Perolehan skill } \\
\text { dari CBL }\end{array}$ & $\begin{array}{l}\text { - } \quad \text { Belajar mengidentifikasi masalah dalam kasus } \\
\text { - } \quad \text { Memicu munculnya pertanyaan untuk diskusi } \\
\text { - } \quad \text { Mengambil keputusan untuk menyelesaikan masalah } \\
\text { - } \quad \text { Tertarik menemukan jurnal yang sesuai } \\
\text { - } \quad \text { Belajar mandiri memahami materi dan kasus } \\
\text { Kendala CBL }\end{array}$ \\
\hline $\begin{array}{l}\text { Penguasaan } \\
\text { Materi dan } \\
\text { Kasus }\end{array}$ & $\begin{array}{l}\text { - Harus memahami teori sekaligus kasus yang masih } \\
\text { baru/asing/belum familiar/jarang ditemui di soal latihan } \\
\text { - } \quad \text { Membutuhkan waktu lebih banyak dalam memahami kasus } \\
\text { - Kesulitan mengidentifikasi masalah dan solusi }\end{array}$ \\
\hline $\begin{array}{l}\text { Kebutuhan skill } \\
\text { lainnya }\end{array}$ & $\begin{array}{l}\text { - } \quad \text { Membutuhkan fokus dan teliti dalam menangani kasus } \\
\text { - Membutuhkan usaha kerja sama tim yang lebih dalam memahami } \\
\text { materi dan kasus }\end{array}$ \\
\hline Teknis & $\begin{array}{l}\text { - Sinyal internet karena pandemi yang membuat pembahasan } \\
\text { kurang optimal }\end{array}$ \\
\hline
\end{tabular}

Tabel 3. Perbedaan Persepsi atas Skill CBL dan Kinerja berdasarkan Tingkat Motivasi

\begin{tabular}{|c|c|c|c|}
\hline \multirow[t]{2}{*}{ Variabel } & \multicolumn{2}{|c|}{ Rata-rata } & \multirow[t]{2}{*}{ Sig. } \\
\hline & $\begin{array}{c}\text { Mahasiswa } \\
\text { Memiliki Motivasi } \\
\text { Tinggi }\end{array}$ & $\begin{array}{c}\text { Mahasiswa } \\
\text { Memiliki Motivasi } \\
\text { Rendah }\end{array}$ & \\
\hline Persepsi & 4.40 & 3.89 & $* * *$ \\
\hline Kinerja & 4.15 & 3.67 & $* * *$ \\
\hline & $\begin{array}{r}\text { Jumlah mahasiswa } \\
(\mathrm{n})=31\end{array}$ & $\begin{array}{r}\text { Jumlah mahasiswa } \\
(\mathrm{n})=34\end{array}$ & \\
\hline
\end{tabular}

Keterangan: $* * *$ signifikan pada $1 \%$

Berdasarkan Tabel 3, rata-rata motivasi mahasiswa kelas CBL adalah 3.78. Dari 65 responden di kelas CBL, terdapat 2 kategori yaitu 31 mahasiswa dengan motivasi lebih tinggi dan 34 mahasiswa dengan motivasi lebih rendah dari skor rata-rata motivasi. Hasil menunjukkan bahwa ada perbedaan persepsi atas CBL dan kinerja belajar berdasarkan tingkat motivasi yang mengkonfirmasi hipotesis 4 dan 5. Mahasiswa dengan motivasi tinggi memiliki persepsi positif atas CBL yang lebih tinggi, yaitu 4.40 dan kinerja belajar yang lebih baik, yaitu 4.15 dibandingkan mahasiswa dengan motivasi rendah yang memiliki persepsi dan kinerja belajar yang lebih rendah, yaitu 3.89 dan 3.67. Dengan demikian, motivasi yang tinggi penting dalam pembentukan persepsi CBL yang positif dan kinerja belajar yang lebih baik.

\section{Pembahasan}

Berdasarkan Tabel 1, secara umum mahasiswa menyatakan pembahasan kasus di kelas dapat meningkatkan skill, namun pada studi ini ditemukan tidak ada perbedaan persepsi atas pembelajaran berbasis kasus yang diterapkan dikelas, hasil tersebut juga tidak ditemukan adanya perbedaan pada motivasi, serta kinerja antara kelas eksperimen (berbasis kasus) dan kelas kontrol (berbasis instruksional). Pada penelitian ini juga ditemukan bahwa motivasi mahasiswa pada kelas berbasis kasus tetap lebih tinggi daripada kelas instruksional namun tidak ditemukan adanya perbedaan mengenai efektivitas kinerja dalam kelas eksperimen maupun kontrol. Hasil ini berbeda dengan hasil penelitian sebelumnya terkait efektivitas 
pembelajaran berbasis kasus. Namun, perbedaan ini dapat dijelaskan oleh temuan Lyons \& Bandura (2019) bahwa tidak ada perbedaan kinerja antara kelompok yang dilatih dengan kasus dan tanpa kasus yang mana pembelajaran berbasis kasus belum menunjukkan dampak ke kinerja dalam jangka pendek. Hasil ini dapat dijelaskan dengan beberapa alasan.

Pertama, pembelajaran berbasis kasus dapat lebih efektif jika dilakukan dengan jumlah peserta yang kecil (Lyons \& Bandura, 2019), sedangkan studi ini menggunakan jumlah peserta yang relatif banyak yaitu sebesar 65 mahasiswa pada kelas eksperimen. Kedua, temuan dapat dikaitkan dengan waktu diterapkannya pembelajaran berbasis kasus pada penelitian ini relatif pendek yaitu 4 pekan, Menurut Lyons \& Bandura (2019), efektivitas pembelajaran berbasis kasus akan berdampak pada peningkatan kinerja jika dilakukan dalam jangka waktu yang panjang. Penerapan pembelajaran berbasis kasus dengan jangka pendek ini dapat memicu kurang meratanya pemahaman mengenai kasus pada semua mahasiswa yang dilakukan eksperimen. Selain itu, perlu diketahui lebih lanjut mengenai sejauh mana materi kasus yang ada dapat memotivasi mahasiswa untuk menjalani pembelajaran berbasis kasus dan memiliki persepsi atas skill pada kelas eksperimen tersebut (Bowe et al., 2009). Sebagaimana disajikan di Tabel 3, ternyata motivasi penting untuk membangun persepsi perolehan skill dari pembelajaran berbasis kasus dan peningkatan kinerja belajar mahasiswa. Dalam hal ini, tingkat motivasi belajar mahasiswa menjadi penting karena hal tersebut akan mempengaruhi tingkat efektivitas pembelajaran berbasis kasus dalam meningkatkan skill dan kinerja mahasiswa.

Oleh karena itu, hasil penelitian ini juga menunjukkan ada perbedaan motivasi mahasiswa yang mengakibatkan persepsi atas skill pada pembelajaran berbasis kasus juga berbeda. Pembahasan kasus dikelas seharusnya dapat memberikan pengalaman belajar yang menyenangkan, sehingga meningkatkan motivasi dan belajar mandiri dengan keingintahuan yang lebih (Nkhoma et al., 2014; Raza et al., 2020; Yoo et al., 2010). Namun, perbedaan tingkat motivasi di antara mahasiswa dapat dikarenakan perbedaan keahlian dasar mahasiswa untuk mengerjakan studi kasus yang tidak merata. Beberapa keahlian dasar yang harus dimiliki oleh mahasiswa dalam menyelesaikan kasus yang diberikan antara lain kemampuan identifikasi masalah, menentukan asumsi, dan memberikan solusi yang membutuhkan high-order thinking yang mana tidak semua mahasiswa memliki kemampuan yang sama dalam menyelesaikan kasus (Nkhoma et al., 2014; Heitzmann, 2008).

Ketiga, dalam menyelesaikan permasalahan dan kasus yang diberikan, mahasiswa akan menelusuri kasus sejenis yang sebelumnya pernah ditemui, dari ingatan sebelumnya ini mereka mencoba untuk menganalogikan dengan kasus saat ini dan mengaplikasikan solusi sebelumnya di kasus yang diberikan (Ketler, 1993). Oleh karena itu, pengalaman mahasiswa dalam membaca atau menemui masalah sejenis juga menjadi faktor yang mengakibatkan persepsi skill pembelajaran berbasis kasus yang diperoleh mahasiswa menjadi berbeda. Selain itu, pada Jurusan Akuntansi Universitas Negeri Malang mata kuliah akuntansi syariah ditempuh oleh mahasiswa semester 2 yang bisa jadi terdapat variasi kemampuan mahasiswa dalam mengenal masalah. Padahal dalam pembelajaran berbasis kasus para mahasiswa dituntut untuk memiliki pengetahuan dasar dan pengenalan kasus yang terjadi sebelumnya untuk memecahkan permasalahan yang ada (Williams, 2005).

Sebagaimana ditampilkan di Tabel 2, mahasiswa memerlukan waktu dan upaya lebih dalam memahami teori sekaligus kasus yang diberikan, pada kelas eksperimen terdapat juga mahasiswa yang masih benar-benar asing dan belum familier dengan kasus yang telah diberikan. Dengan kata lain, terdapat beberapa mahasiswa yang mengalami kesulitan untuk memahami masalah dan solusi atas kasus yang ada (Ketler, 1993).

Dengan demikian, jumlah peserta dalam kelas, motivasi, pengalaman, dan situasi individu mahasiswa menjadi alasan mengapa pembelajaran berbasis kasus tidak terlihat efektivitasnya secara merata bagi seluruh mahasiswa. Mahasiswa di satu sisi memperoleh penguasaan materi dan kasus dengan skill lebih baik (Raza et al., 2020; Nkhoma et al., 2014; Mostafa et al., 2019), tetapi di sisi lain mahasiswa menghadapi kesulitan untuk mempelajari kasus yang diberikan.

Tabel 3 memberikan penekanan bahwa motivasi penting dalam memberi persepsi kebermanfaatan pembelajaran berbasis kasus dan kinerja mahasiswa. Motivasi dapat membuat mahasiswa lebih bersemangat, sehingga mempersepsikan dapat memperoleh skill yang lebih baik dari pembelajaran berbasis kasus. Selain itu, motivasi juga mengakibatkan mahasiswa memiliki kinerja yang lebih baik (Ames \& Archer, 1988) seperti merasa pembelajaran telah efektif, mudah, cepat dipahami, serta kepuasan belajar dapat tercapai (Deci et al., 2001; Dahl \& Smimou, 2011). Oleh karena itu, perlu upaya pengoptimalan motivasi pada mahasiswa untuk meningkatkan persepsi dan kinerja belajar (Hytti et al., 2010; Dahl \& Smimou, 2011). 


\section{Simpulan, Implikasi, dan Saran}

Kebutuhan industri akan sumber daya manusia yang siap untuk bekerja menjadi hal yang sangat penting bagi perguruan tinggi. Untuk itu, perguruan tinggi sudah semestinya membuat pembelajaran yang dapat mempersiapkan mahasiswa di dunia kerja nantinya. Pembelajaran berbasis kasus dirasa menjadi salah satu metode belajar yang dapat meningkatkan skill guna siap pada dunia kerja. Studi ini menginvestigasi efektivitas pembelajaran berbasis kasus yang dilihat dari motivasi, persepsi, dan kinerja mahasiswa dibandingkan dengan kelas instruksional. Hasil penelitian ini menunjukkan tidak ada perbedaan persepsi, motivasi, dan kinerja antara kelas pembelajaran berbasis kasus dengan kelas instruksional.

Beberapa alasan yang dapat mengakibatkan kurang optimalnya pembelajaran berbasis kasus adalah faktor kuantitas peserta didik dalam satu kelas, yang mana pembelajaran berbasis kasus akan lebih efektif jika peserta didik pada satu kelas lebih kecil. Faktor lain adalah terkait dengan pengalaman mahasiswa dalam memahami dan mengidentifikasi kasus yang diberikan. Mata kuliah akuntansi syari'ah di Jurusan Akuntansi Universitas Negeri Malang ditempuh pada semester 2. Hal ini mempengaruhi pemahaman peserta didik akan kasus yang diberikan karena pengalaman mereka dalam mengidentifikasi serta menganalisis kasus masih tergolong kurang. Oleh karena itu, mahasiswa dengan semester 4 ke atas mungkin saja akan memberikan hasil yang lebih optimal pada pembelajaran berbasis kasus karena mereka sudah terbiasa mendapatkan kasus dan permasalahan pada mata kuliah yang telah ditempuh sebelumnya. Selanjutnya, pada pembelajaran berbasis kasus, diperlukan waktu yang relatif lebih lama untuk mendapatkan kinerja yang lebih baik.

Pada studi ini juga ditemukan bahwa motivasi menjadi variabel yang sangat penting dalam meningkatkan persepsi skill dan kinerja belajar pada pembelajaran berbasis kasus. Oleh karena itu, peningkatan motivasi peserta didik menjadi penting dalam proses pembelajaran di kelas.

Studi ini memiliki kontribusi pada pengembangan keilmuan di bidang pengembangan inovasi pembelajaran. Selain hal tersebut, penelitian ini juga dapat melihat proses dan kendala penerapan pembelajaran berbasis kasus pada mata kuliah akuntansi syari'ah yang ada di Universitas Negeri Malang. Temuan pada penelitian ini bermanfaat bagi regulator dan pengajar dalam menyusun dan mengembangkan kebijakan mengenai pembelajaran serta kebijakan lain yang mendukung perbaikan pembelajaran di Indonesia pada umumnya.

Saran bagi penelitian selanjutnya dapat melakukan observasi pembelajaran berbasis kasus untuk periode yang lebih lama. Selain hal tersebut, faktor-faktor lain yang dapat menyebabkan perbedaan efektivitas CBL dalam meningkatkan persepsi atas keahlian dan kinerja belajar juga harus diperhatikan. Faktor-faktor tersebut dapat merupakan aspek teknis seperti jumlah mahasiswa dalam kelas; serta perbedaan individual seperti gender, latar belakang pendidikan sebelumnya, atau kemampuan mahasiswa menganalisis kasus. Selain itu, implementasi pembelajaran berbasis kasus dapat diuji pada pembelajaran luring untuk menambah literatur atas efektivitas pembelajaran kasus.

\section{References}

Ames, C., \& Archer, J. (1988). Achievement Goals in the Classroom: Students' Learning Strategies and Motivation Processes. Journal of Educational Psychology, 80(3), 260-267. https://doi.org/10.1037/0022-0663.80.3.260

Barnes, L. B., Christensen, C. R., \& Abby, J. H. (1994). Teaching and the Case Method: Text, Cases, and Readings. Harvard Business Review Press.

Bowe, C. M., Voss, J., \& Aretz, H. T. (2009). Case method teaching: An effective approach to integrate the basic and clinical sciences in the preclinical medical curriculum. Medical Teacher, 31(9), 834-841. https://doi.org/10.1080/01421590902922904

Cinneide, B. O. (1997). The role and effectiveness of case studies: student performance in case study vs 'theory' examinations. Journal of European Industrial Training, 21(1), 3-13. https://doi.org/https://doi.org/10.1108/03090599710156384

Dahl, D. W., \& Smimou, K. (2011). Intrinsic \& Extrinsic Motivation_dahl2011.pdf. Managerial Finance, 37(7), 582-609. https://doi.org/http://dx.doi.org/10.1108/03074351111140243

Deci, E. L. (1971). Effects of externally mediated rewards on intrinsic motivation. Journal of Personal Soc. Psychology, 18, 105-115.

Deci, Edward L., Ryan, R. M., Gagné, M., Leone, D. R., Usunov, J., \& Kornazheva, B. P. (2001). Need satisfaction, motivation, and well-being in the work organizations of a former eastern bloc country: A crosscultural study of self-determination. Personality and Social Psychology Bulletin, 27(8), 930-942. https://doi.org/10.1177/0146167201278002

Fordham, A. (1980). Student intrinsic motivation, science teaching practices and student learning. Research 
in Science Education, 10, 107-117.

Giacalone, D. (2016). Enhancing student learning with case-based teaching and audience response systems in an interdisciplinary Food Science course. Higher Learning Research Communications, 6(3). https://doi.org/10.18870/hlrc.v6i3.304

Golaghaie, F., Asgari, S., Khosravi, S., Ebrahimimonfared, M., Mohtarami, A., \& Rafiei, F. (2019). Integrating case-based learning with collective reflection: outcomes of inter-professional continuing education. Reflective Practice, 20(1), 42-55. https://doi.org/10.1080/14623943.2018.1539660

Grassberger, R., \& Wilder, S. (2015). Impacting student learning using a living case study. Higher Education, Skills and Work-Based Learning, 5(4), 369-382. https://doi.org/10.1108/HESWBL-05-2015-0030

Heinrich, C., Pennington, R. R., \& Kuiper, R. (2012). Virtual Case Studies in the Classroom Improve Student Knowledge. Clinical Simulation in Nursing, 8(8), e353-e361. https://doi.org/10.1016/j.ecns.2011.02.002

Heitzmann, R. (2008). Case study instruction in teacher education: opportunity to develop students' critical thinking, school smarts and decision making. Education, 128(4), 523-542.

Hytti, U., Stenholm, P., Heinonen, J., \& Seikkula-Leino, J. (2010). Perceived learning outcomes in entrepreneurship education: The impact of student motivation and team behaviour. Education and Training, 52(8), 587-606. https://doi.org/10.1108/00400911011088935

Kardash, C. A. M., \& Wallace, M. L. (2001). The perceptions of science classes survey: What undergraduate science reform efforts really need to address. Journal of Educational Psychology, 93(1), 199-210. https://doi.org/10.1037/0022-0663.93.1.199

Ketler, K. (1993). Case-based reasoning: An introduction. Expert Systems With Applications, 6(1), 3-8. https://doi.org/10.1016/0957-4174(93)90014-W

Kim, H. J., Pederson, S., \& Baldwin, M. (2012). Improving user satisfaction via a case-enhanced e-learning environment. Education and Training, 204-218. https://doi.org/10.1108/00400911211210305

Kolodner, J.L., \& Leake, D. B. (1996). A tutorial introduction to case-based reasoning. In D. Leake (Ed.), CaseBased Reasoning: Experiences, Lessons and Future Directions (pp. 81-92). AAAI Press. http://www.jimdavies.org/summaries/kolodner1996-2.html

Kolodner, Janet L. (1997). Educational implications of analogy: A view from case-based reasoning. American Psychologist, 52(1), 57-66. https://doi.org/10.1037//0003-066x.52.1.57

Lee, S. hee, Lee, J., Liu, X., Bonk, C. J., \& Magjuka, R. J. (2009). A review of case-based learning practices in an online MBA program: A program-level case study. Educational Technology and Society, 12(3), 178190. https://www.ds.unipi.gr/et\&s/journals/12_3/16.pdf

Li, S., Ye, X., \& Chen, W. (2019). Practice and effectiveness of "nursing case-based learning" course on nursing student's critical thinking ability: A comparative study. Nurse Education in Practice, 36, 91-96. https://doi.org/10.1016/j.nepr.2019.03.007

Lyons, P., \& Bandura, R. P. (2019). Case-based modeling: fostering expertise development and small group learning. European Journal of Training and Development, 43(7-8), 767-782. https://doi.org/10.1108/EJTD-01-2019-0009

Lyons, P., \& Bandura, R. P. (2020a). Skills needs, integrative pedagogy and case-based instruction. Journal of Workplace Learning, 32(7), 473-487. https://doi.org/10.1108/JWL-12-2019-0140

Lyons, P., \& Bandura, R. P. (2020b). Stimulating employee learning: the confluence of case-based and selfregulated learning. Industrial and Commercial Training, 52(3), 171-183. https://doi.org/10.1108/ICT-12-2019-0109

McCabe, P., Purcell, A., Baker, E., Madill, C., \& Trembath, D. (2009). Case-based learning: One route to evidence-based practice. Evidence-Based Communication Assessment and Intervention, 3(4), 208-219. https://doi.org/10.1080/17489530903399145

Mesthrige, J. W., Lam, P. T. I., Chiang, Y. H., \& Samarasinghalage, T. I. (2020). Effectiveness of Case-based Learning: Views of Construction and Real Estate Students. International Journal of Construction Education and Research, 00(00), 1-15. https://doi.org/10.1080/15578771.2020.1758254

Mostafa, B., Shekoofeh, H., Khatereh, R., Simin, S., Kobra, S.-K., \& Afsaneh, G. (2019). Acomparative study of the effectiveness of case-based learning and lecturing in enhancing nursing students' skills in diagnosing cardiac dysrhythmias. Revista Latinoamericana de Hipertension, 14(6), 651-655. https://www.redalyc.org/journal/1702/170262862005/html/

Nenninger, P. (2014). Task motivation: an interaction between the cognitive and context oriented dimensions in learning. In K. A. Renninger, S. Hidi, \& A. Krapp (Eds.), The Role of Interest in Learning and Development. Erlbaum. https://doi.org/https://doi.org/10.4324/9781315807430

Nkhoma, M., Sriratanaviriyakul, N., Cong, H. P., \& Lam, T. K. (2014). Examining the mediating role of learning engagement, learning process and learning experience on the learning outcomes through localized 
real case studies. Education and Training, 56(4), 287-302. https://doi.org/10.1108/ET-01-20130005

Nkhoma, M. Z., Lam, T. K., Sriratanaviriyakul, N., Richardson, J., Kam, B., \& Lau, K. H. (2017). Unpacking the Revised Bloom's Taxonomy: Developing Case-Based Learning Activities. Education and Training, $59(3), 250-264$.

Noels, K. A., Clement, R., \& Pelletier, L. G. (1999). Perceptions of teachers' communicative style and students' intrinsic and extrinsic motivation. The Modern Language Journal, 83(1), 23-34.

Otoritas Jasa Keuangan (OJK). (2020). Laporan Perkembangan Keuangan Syariah Indonesia. In Otoritas Jasa Keuangan. https://www.ojk.go.id/id/kanal/syariah/data-dan-statistik/laporan-perkembangankeuangan-syariah-indonesia/Documents/LAPORAN PERKEMBANGAN KEUANGAN SYARIAH INDONESIA 2019.pdf

Parrado-Martínez, P., \& Sánchez-Andújar, S. (2020). Development of competences in postgraduate studies of finance: A project-based learning (PBL) case study. International Review of Economics Education, 35(July). https://doi.org/10.1016/j.iree.2020.100192

Plaks, J. E., Dweck, C. S., \& Grant, H. (2005). Violations of implicit theories and the sense of prediction and control: Implications for motivated person perception. Journal of Personality and Social Psychology, 88(2), 245-262. https://doi.org/10.1037/0022-3514.88.2.245

Prince, M. (2004). Does active learning work? A review of the research. Journal of Engineering Education, 93(3), 223-231.

Raza, S. A., Qazi, W., \& Umer, B. (2020). Examining the impact of case-based learning on student engagement, learning motivation and learning performance among university students. Journal of Applied Research in Higher Education, 12(3), 517-533. https://doi.org/10.1108/JARHE-05-2019-0105

Reeve, J., Deci, E. L., \& Ryan, R. M. (2004). Self-determination theory: a dialectical framework for understanding socio-cultural influences on student motivation. In S. Van Etten \& M. Pressley (Eds.), Big Theories Revisited (pp. 31-60). Information Age Press.

Sawyer, A. J., Tomlinson, S. R., \& Maples, A. J. (2000). Developing essential skills through case study scenarios. Journal of Accounting Education, 18(3), 257-282. https://doi.org/10.1016/s07485751(00)00019-1

Sugeng, B., \& Suryani, A. W. (2019). Enhancing the learning performance of passive learners in a financial management class using problem-based learning. Journal of University Teaching and Learning Practice, 17(1). https://doi.org/10.53761/1.17.1.5

Topperzer, M. K., Roug, L. I., Andres-Jensen, L., Pontoppidan, P., Hoffmann, M., Larsen, H. B., Schmiegelow, K., \& Sorensen, J. . L. (2021). Twelve tips for postgraduate interprofessional case-based learning. Medical Teacher, 43(7), 1-14. https://doi.org/https://doi.org/10.1080/0142159X.2021.1896691

Williams, B. (2005). Case based learning - A review of the literature: Is there scope for this educational paradigm in prehospital education? Emergency Medicine Journal, 22(8), 577-581. https://doi.org/10.1136/emj.2004.022707

Yoo, M. S., Park, J. H., \& Lee, S. R. (2010). The effects of case-based learning using video on clinical decision making and learning motivation in undergraduate nursing students. Journal of Korean Academy of Nursing, 40(6), 863-871. https://doi.org/10.4040/jkan.2010.40.6.863 